\title{
CHRONOLOGY OF THE BURIALS WITH ANIMAL-STYLE HORSE HARNESS FROM THE PRIKUBANSKY BURIAL GROUND ${ }^{1}$
}

\author{
Natalya Yu. Limberis \\ Kuban State University, Krasnodar, Russian Federation \\ Ivan I. Marchenko \\ Kuban State University, Krasnodar, Russian Federation
}

\begin{abstract}
The paper presents the description of findings - horse bronze cheekpieces and forehead pieces - from the Prikubansky burial ground (the Krasnodar region). This burial ground is a standard of the Maeotian culture of the $4^{\text {th }}-$ early $3^{\text {rd }} \mathrm{cc}$. BC. More than 350 burials with amphorae and black glazed ceramic vessels have been discovered in this burial ground. The sets of the horse harness with the iron bit, bronze cheekpieces and forehead pieces made in Maeotian-Scythian animal style, were found in 9 burials. The pairs of cheekpieces are gamma-shaped, the round shaft swells to figure 8. Its zoomorphic plaques show the stylized horns and heads of deer, wolf and griffin. The forehead pieces are openwork or in the form of the figure of the lying wolf, with a horizontal attachment loop on the reverse. The linear engraving on the openwork plaques is typical of the Maeotian-Scythian art in the Kuban region. The burials of the horsemen included the different inventory and Greek amphorae of many Mediterranean centers (Heracleia, Sinop, Mende, Thassos, Kos, Cnidus, Ikos). Most complexes contained 2 and even 3 amphorae. The combination of the different centers and types of amphorae makes it possible to date narrowly every burial and the set of horse harness. Generally, the chronology of the burials with the horse harness made in the MaeotianScythian animal style is limited within the second - third quarters of the $4^{\text {th }}$ century BC. Only one burial, destroyed in ancient times (with one amphora), has wide chronology ranges within the first - third quarter of the fourth century.

Morphology and typology of horse harness have been developed by N.Yu. Limberis, the chronology of complexes - by I.I. Marchenko.

Key words: Maeotian culture, burial ground, horse bronze cheekpieces, forehead pieces, Maeotian-Scythian animal style, chronology.

Citation. Limberis N.Yu., Marchenko I.I. Chronology of the Burials with Animal-Style Horse Harness from the Prikubansky Burial Ground. Vestnik Volgogradskogo gosudarstvennogo universiteta. Seriya 4, Istoriya. Regionovedenie. Mezhdunarodnye otnosheniya [Science Journal of Volgograd State University. History. Area Studies. International Relations], 2018, vol. 23, no. 3, pp. 99-113. (in Russian). DOI: https://doi.org/10.15688/ jvolsu4.2018.3.9

УДК 930.26(470+571)

Дата поступления статьи: 28.02.2018

ББК 63.48(2) Дата принятия статьи: 10.04 .2018
\end{abstract}

\section{ХРОНОЛОГИЯ ПОГРЕБЕНИЙ С КОНСКОЙ УПРЯЖЬЮ В ЗВЕРИНОМ СТИЛЕ ИЗ ПРИКУБАНСКОГО МОГИЛЬНИКА ${ }^{1}$}

\author{
Наталья Юрьевна Лимберис \\ Кубанский государственный университет, г. Краснодар, Российская Федерация \\ Иван Иванович Марченко \\ Кубанский государственный университет, г. Краснодар, Российская Федерация
}




\section{РАННИЙ ЖЕЛЕЗНЫЙ ВЕК}

Аннотация. Статья посвящена находкам бронзовых конских псалиев и налобников из грунтового могильника Прикубанский в Краснодарском крае. Этот могильник является эталонным для меотской культуры IV - начала III в. до н. э. Из него происходят более 350 комплексов с амфорной тарой и чернолаковой керамикой. Наборы конской упряжи с бронзовыми псалиями и налобниками, выполненными в меото-скифском зверином стиле, были найдены в девяти погребениях. Псалии Г-образной формы с 8-образным расширением. На зооморфных пластинах изображены стилизованные рога и головы оленей, волков и грифонов. Налобники ажурные или в виде фигуры лежащего волка, с петлей для крепления с обратной стороны. Пластины оконтурены гравированными линиями, что является типичным для меото-скифского звериного стиля Прикубанского региона. Погребения всадников сопровождались разнообразным инвентарем и греческими амфорами многих средиземноморских центров производства (Гераклея, Синопа, Менда, Фасос, Кос, Книд, Икос). В большинстве комплексов встречено по 2 и даже 3 амфоры. Сочетание амфор разных центров и типов дает возможность установить узкие датировки для каждого погребения и набора конской узды. В целом, хронология погребений с бронзовой конской упряжью, выполненной в меото-скифском зверином стиле, ограничивается главным образом второй - третьей четвертями IV в. до н. э. Только одно ограбленное в древности погребение (с одной амфорой) широко датируется в пределах первой - третьей четвертей этого столетия.

Морфология и типология конской узды разработаны Н.Ю. Лимберис, хронология комплексов И.И. Марченко.

Ключевые слова: меотская культура, могильник, конские бронзовые псалии, налобники, меото-скифский звериный стиль, хронология.

Цитирование. Лимберис Н. Ю., Марченко И. И. Хронология погребений с конской упряжью в зверином стиле из Прикубанского могильника // Вестник Волгоградского государственного университета. Серия 4, История. Регионоведение. Международные отношения. - 2018. - T. 23, № 3. - С. 99-113. - DOI: https:// doi.org/10.15688/jvolsu4.2018.3.9

Раскопанный в 1998-2001 гг. Краснодарской экспедицией КубГУ могильник у хут. Прикубанский является эталонным памятником для меотской культуры IV - начала III в. до н. э. Из него происходят более 350 комплексов с амфорной тарой и чернолаковой керамикой. Настоящая работа посвящена погребениям всадников, в которых присутствовали наборы конской упряжи с литыми бронзовыми псалиями и налобниками, выполненными в меото-скифском зверином стиле [1, с. 104]. Благодаря находкам в этих погребениях амфор имеется возможность установить не только узкую хронологию каждого комплекса, но и более точные даты для каждого комплекта конской узды без привлечения отдаленных аналогий.

Во всех девяти захоронениях с бронзовой упряжью были найдены однотипные железные двухчастные удила с загнутыми в петли окончаниями. Петли не сомкнуты. Внутренние петли удил меньше внешних. Грызла в сечении обычно круглые, но встречаются и квадратные. Многие удила снабжены строгими насадками, которые представлены тремя разновидностями: а) короткая крестовина с загнутыми острыми шипами; б) короткая крестовина, концы которой раскованы в плоские лопасти с зубцами; в) квадратная пластина с загнутыми в виде шипов углами. Бронзовые детали упряжи (псалии и налобники) - литые. Псалии относятся к типу Г-образных, с 8-видными расширениями на стержне; налобники пластинчатые, с петлей для крепления на обратной стороне.

Из погребения 33 (см. рис. 1) происходит пара псалиев, зооморфные пластины которых выполнены в виде стилизованной головы оленя в фас с ветвистыми рогами, и налобник в виде фигуры лежащего волка с оскаленной пастью. Детали изображения (ухо, глаз, лапа, хвост, шерсть) проработаны гравировкой. В этом погребении были найдены две амфоры. Первая амфора (синопская, пифоидного типа, варианта II-A-1) датируется второй четвертью IV в. до н. э. [3, c. 149,160 , табл. 101,5$]$. Хронология второй амфоры (производства мастерских Икоса) охватывает период второй четверти - середины IV в. до н. э. [6, с. 259, рис. 2, 1]. Таким образом, дату комплекса можно ограничить второй четвертью IV века.

В погребении 39 (см. рис. 2) найдена пара псалиев. У одного псалия стержень был обломан в древности. Зооморфные пластины представляют собой зеркальное изображение 
головы оленя в профиль с тремя асимметричными отростками рогов, центральные отростки которых заканчиваются головой хищника (волка?) с длиной гривастой шеей, а боковые головками хищных птиц. Детали изображения (уши, глаза, нос, зубы, грива и рога) подчеркнуты гравированными линиями. В комплект конской узды входил также налобник в виде ажурной пластины, с двумя петлями на обратной стороне. Хронология погребения определяется по амфоре Менды мелитопольского варианта (II-C), которая датируется второй третьей четвертями IV в. до н. э. [3, с. 95]. Этой дате не противоречит и вторая амфора неустановленного центра производства типа Солоха I.

Из погребения 159 (см. рис. 3) происходит пара псалиев с зооморфными пластинами, являющимися зеркальным изображением двух стилизованных волчьих (?) голов на длинных шеях, одна из которых кусает загнутый кольцом хвост или рог оленя, а вторая - загривок первой. Детали изображения (уши, глаза, зубы) проработаны гравировкой. Вместе с удилами был найден бронзовый литой наносник, декорированный в двухстороннем рельефе в виде стилизованной головки грифона, с круглым отверстием для крепления. Кроме этого, в состав уздечного набора входили шесть полусферических массивных блях с центральной петлей для крепления и две бронзовые литые ворворки усеченно-конической формы. В этом погребении были встречены три амфоры. Книдская амфора елизаветовского варианта (I-A) относится ко второй четверти IV в. до н. э. [3, с. 102, 110]. Синопская амфора конического типа, варианта I-А находит ближайшую аналогию в погребении 8 кургана 3 Прикубанского могильника и датируется первой третью IV в. до н. э. [3, с. 146, 147,158 , табл. 100, 2]. Третья - фасосская амфора с магистратским клеймом, которое пока не прочитано, относится к развитой биконической серии (II-B-2), хронология которой определяется в пределах второй - третьей четвертей IV в. до н. э. [3, с. 67-70, 76]. На этом основании погребение можно датировать второй четвертью IV века.

В ограбленном в древности погребении 202 (см. рис. 4) был найден псалий, загнутый конец которого оформлен в виде ноги копытного животного. Детали (пятка и копыто) подчеркнуты гравированными линиями. Это погребение датируется серединой - третьей четвертью IV в. до н. э. по совместной находке двух амфор: неустановленного средиземноморского центра с грибовидным венцом (Солоха I) и книдской, геленджикского варианта [3, с. 102-103, 110].

Пара псалиев с зооморфной пластиной в виде схематичного изображения грифона (?) происходит из погребения № 224 (см. рис. 5). В комплект входил также налобник в виде фигуры лежащего волка. Детали изображения (ухо, глаз, лапа, хвост, шерсть) проработаны гравировкой. В погребении найдены две амфоры типа Солоха I и фасосская, развитой биконической серии (II-B-2) второй - третьей четвертей IV в. до н. э. [3, с. 68, 69, 76]. По амфорам комплекс датируется серединой или, точнее (по определению С.Ю. Монахова), 6040-ми гг. IV в. до н. э. Этой дате не противоречит и присутствие в комплексе чернолакового болсала.

Оформление пары псалиев из погребения 236 (см. рис. 6) близко по стилистике описанным выше псалиям из погребения 159. На ажурных пластинах в зеркальном изображении даны две волчьи или собачьи головы на длинных шеях, с широко раскрытыми пастями. Одна голова кусает голову грифона или какое-то мелкое животное, вторая - загривок первой. Детали изображения (уши, глаза, зубы, ошейники) проработаны гравировкой. Вместе с удилами найден ажурный налобник с ромбовидной центральной частью и подтреугольными концами. Прорезной орнамент подчеркнут тонкими гравированными линиями. Из этого погребения происходят две амфоры. Амфоре неустановленного средиземноморского центра с грибовидным венцом (типа Солоха I) точных аналогий пока не найдено. Поэтому погребение нужно датировать по синопской амфоре пифоидного типа, варианта II-А второй четвертью IV в. до н. э. [3, c. 158].

В погребении 394 (см. рис. 7), ограбленном в древности, был найден один псалий с пластиной в виде двух волчьих (?) голов с раскрытыми пастями, кусающими с двух сторон рог оленя. Детали изображения (уши, глаза, зубы) и периметр пластины проработаны гра- 


\section{РАННИЙ ЖЕЛЕЗНЫЙ ВЕК}

вировкой. Погребение можно датировать второй четвертью IV в. до н. э. по мендейской амфоре варианта портичелло (II-B) (рис. 7, 3), близкой сосудам поздней серии этого варианта [3, с. 92]. Вторая амфора предположительно отнесена к кругу Коринфа (рис. 7, 2).

Пара псалиев из погребения 402 (см. рис. 8) с зооморфными пластинами, изображающими стилизованную голову оленя в фас с ветвистыми рогами, близка псалиям из погребения 33. На одной из пластин изображение подчеркнуто гравировкой. Здесь же найден овальный ажурный налобник со стилизованными рогами оленя. Изображение также подчеркнуто тонкими гравированными линиями. Хронология этого погребения, ограбленного в древности, определяется в рамках первой - третьей четвертей IV в. до н. э. по косской амфоре «раннего» варианта I-A [4, с. 203, рис. 3, 7].

Из погребения 427 (см. рис. 9) происходит один псалий с пластиной в виде двух развернутых влево голов волчьих хищников с раскрытыми пастями. Изображение подчеркнуто гравировкой из заштрихованных полос. Штриховкой показаны зубы, кружками - глаза, завитком - нос. В комплект узды входил также налобник с изображением стилизованной головы лося с рогами. Кружками показаны глаза, две изогнутые линии проведены поперек морды. Края и вырезы пластины подчеркнуты заштрихованными полосами. Кроме того, имеется бронзовая литая бляха в виде головы хищника кошачьей породы, с вертикальной петлей на обратной стороне. Найден- ная в погребении гераклейская амфора пифоидного типа, варианта I-A-2, с клеймом магистрата Спинтара (подгруппа IVБ по В.И. Кацу) датируется 40-ми гг. IV в. до н. э. [3, с. 132, 133,143 ; 2, с. 430, 432, приложение V, 5; VI]. Амфора Икоса относится ко второй группе середины - третьей четверти этого столетия [6, c. 260 , рис. 4,3$]$. Чернолаковый одноручный канфар (кружка) с каннелюрами в нижней части тулова и формованным венчиком по материалам Афинской агоры датируется 375350 гг. до н. э. [8, № 705]. Сосуд этого же типа, но с гладкими стенками, был найден в некрополе Панское I, в комплексе, датированном 360-340 гг. до н.э. [5, с. 138, хрон. табл. 2 , табл. $9,86 ; 7$, с. 167,169 , рис. 6,9$]$. На этом основании хронологическая позиция погребения 427 может быть определена началом третьей четверти IV в. до н. э.

Таким образом, хронология погребений меотских всадников из Прикубанского могильника, сопровождавшихся бронзовой конской упряжью, выполненной в меото-скифском зверином стиле, ограничивается главным образом второй - третьей четвертями IV в. до н. э. Только погребение 402 широко датируется в пределах первой - третьей четвертей этого столетия.

\section{ПРИМЕЧАНИЕ}

1 Работа выполнена при поддержке гранта РФФИ № 18-09-00619 «Военное дело меотов правобережья Кубани (VI в. до н. э. - III в. н. э.)». 


\section{ПРИЛОЖЕНИЯ}
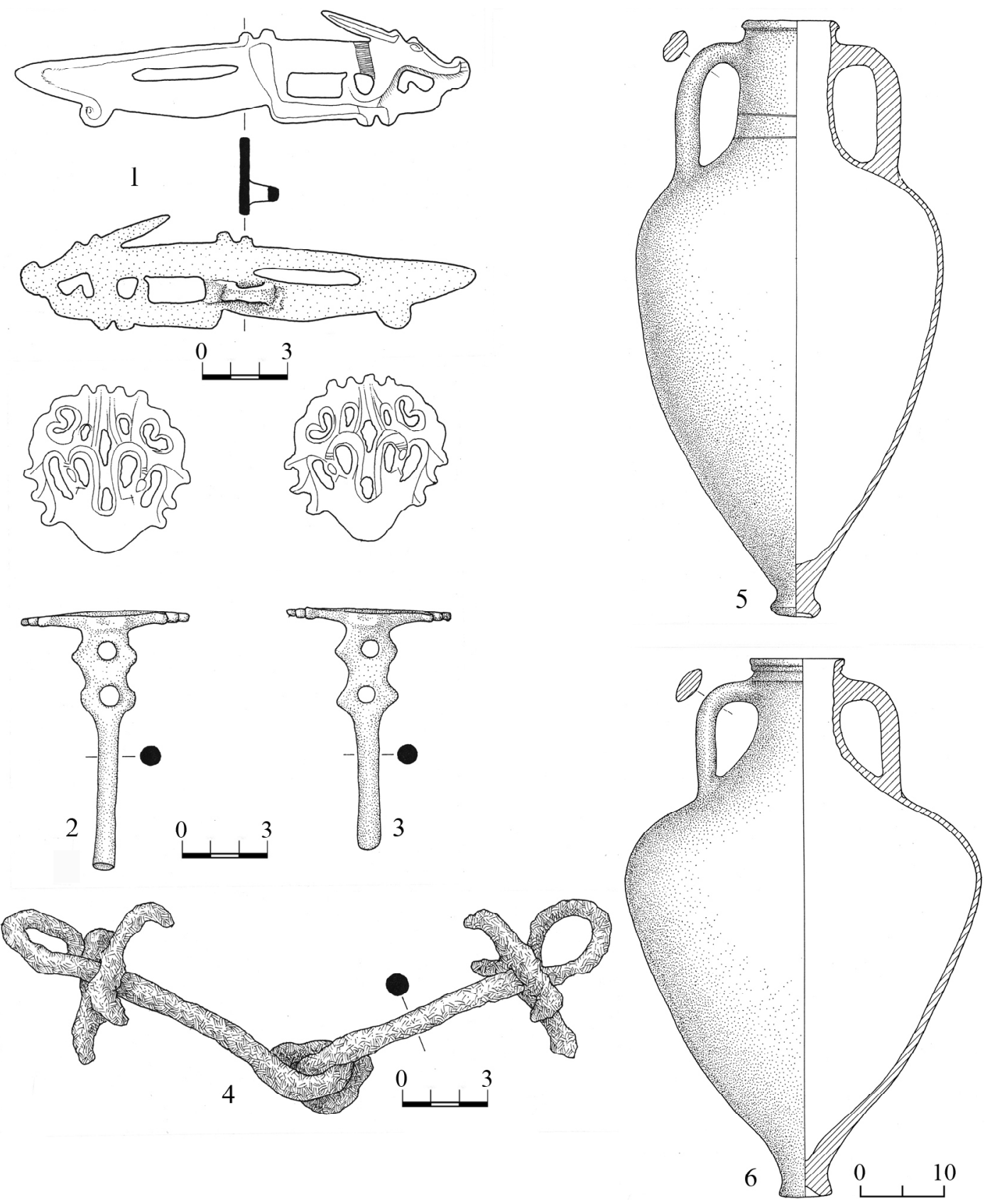

Рис. 1. Прикубанский могильник, погребение 33:

1 - бронзовый налобник; 2, 3 - бронзовые псалии; 4 - железные удила; 5, 6- амфоры

Fig. 1. The Prikubansky burial ground, burial 33:

1 - bronze forehead piece; 2, 3- bronze cheekpieces; 4 - iron bit; 5, 6- amphorae 


\section{РАННИЙ ЖЕЛЕЗНЫЙ ВЕК}
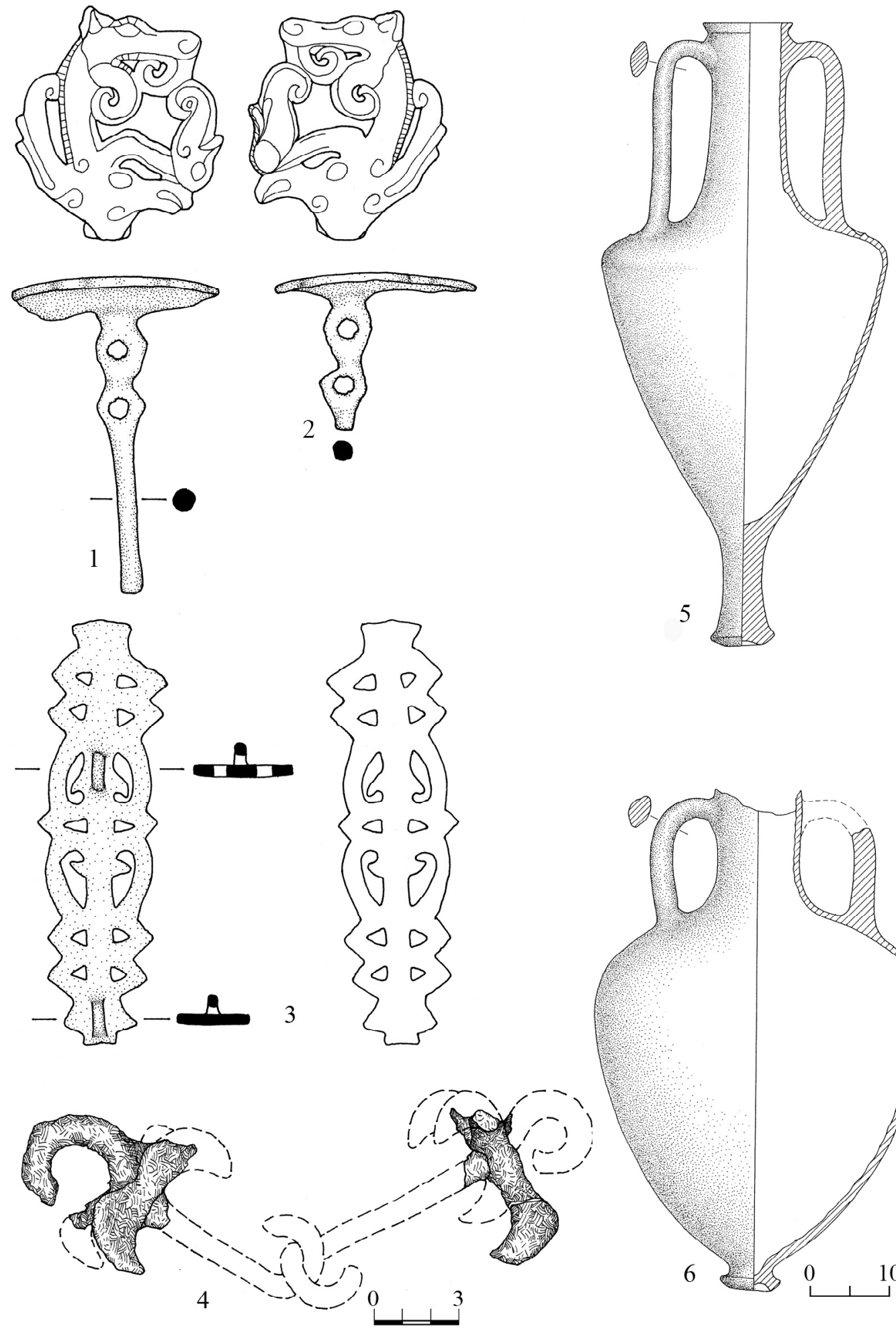

Рис. 2. Прикубанский могильник, погребение 39:

1, 2 - бронзовые псалии; 3 - бронзовый налобник; 4- железные удила; 5, 6- амфоры

Fig. 2. The Prikubansky burial ground, burial 39:

1,2 - bronze cheekpieces; 3 - bronze forehead piece; 4 - iron bit; 5, 6- amphorae 

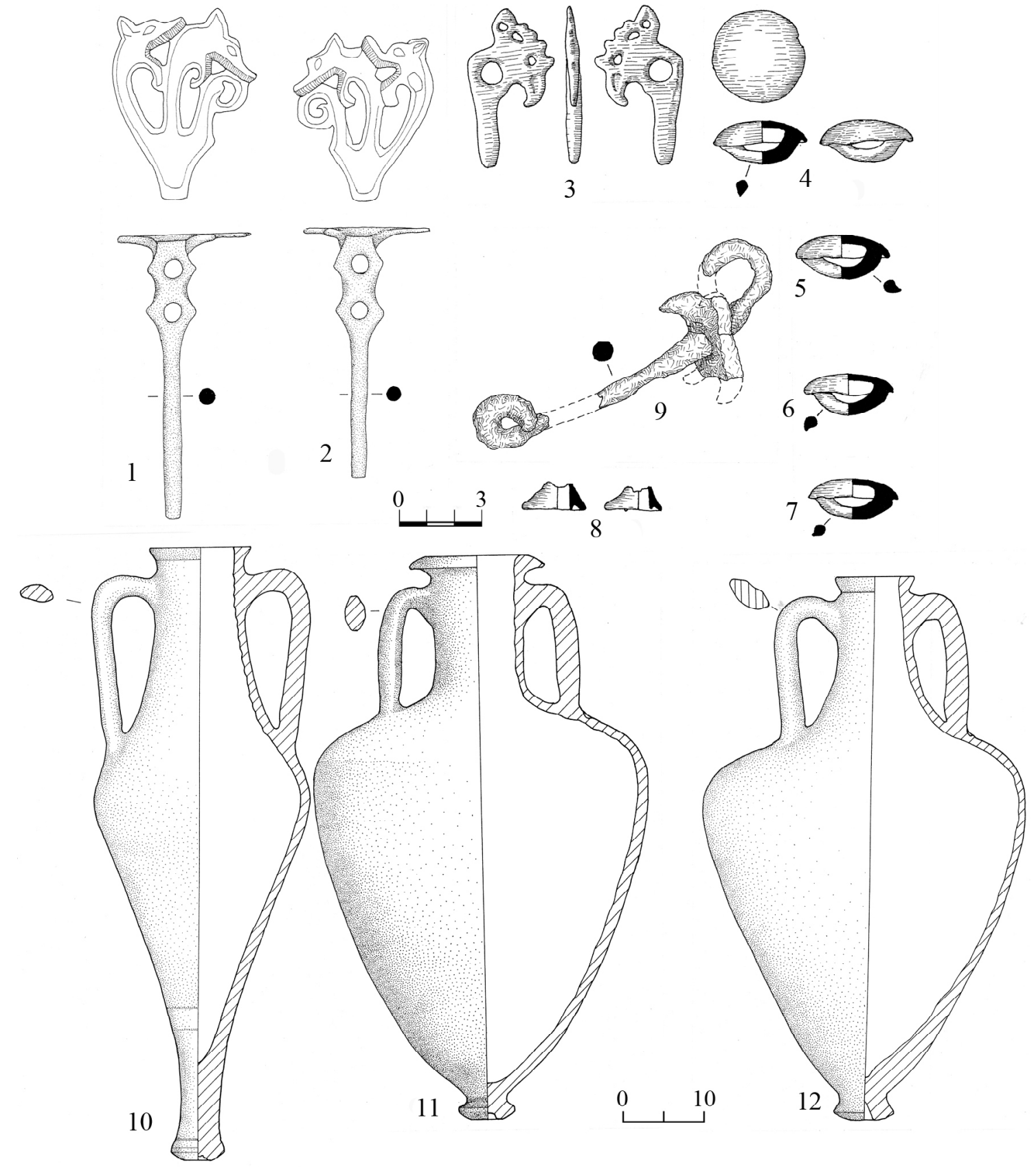

Рис. 3. Прикубанский могильник, погребение 159:

1, 2 - бронзовые псалии; 3 - бронзовый наносник; 4-7 - бронзовые бляхи; 8 - бронзовые ворворки; 9 - железные удила; 10-12 - амфоры

Fig. 3. The Prikubansky burial ground, burial 159:

1, 2 - bronze cheekpieces; 3 - bronze nose piece; $4-7$ - bronze buckles; 8 - bronze finials; 9 - iron bit; 10-12 - amphorae 


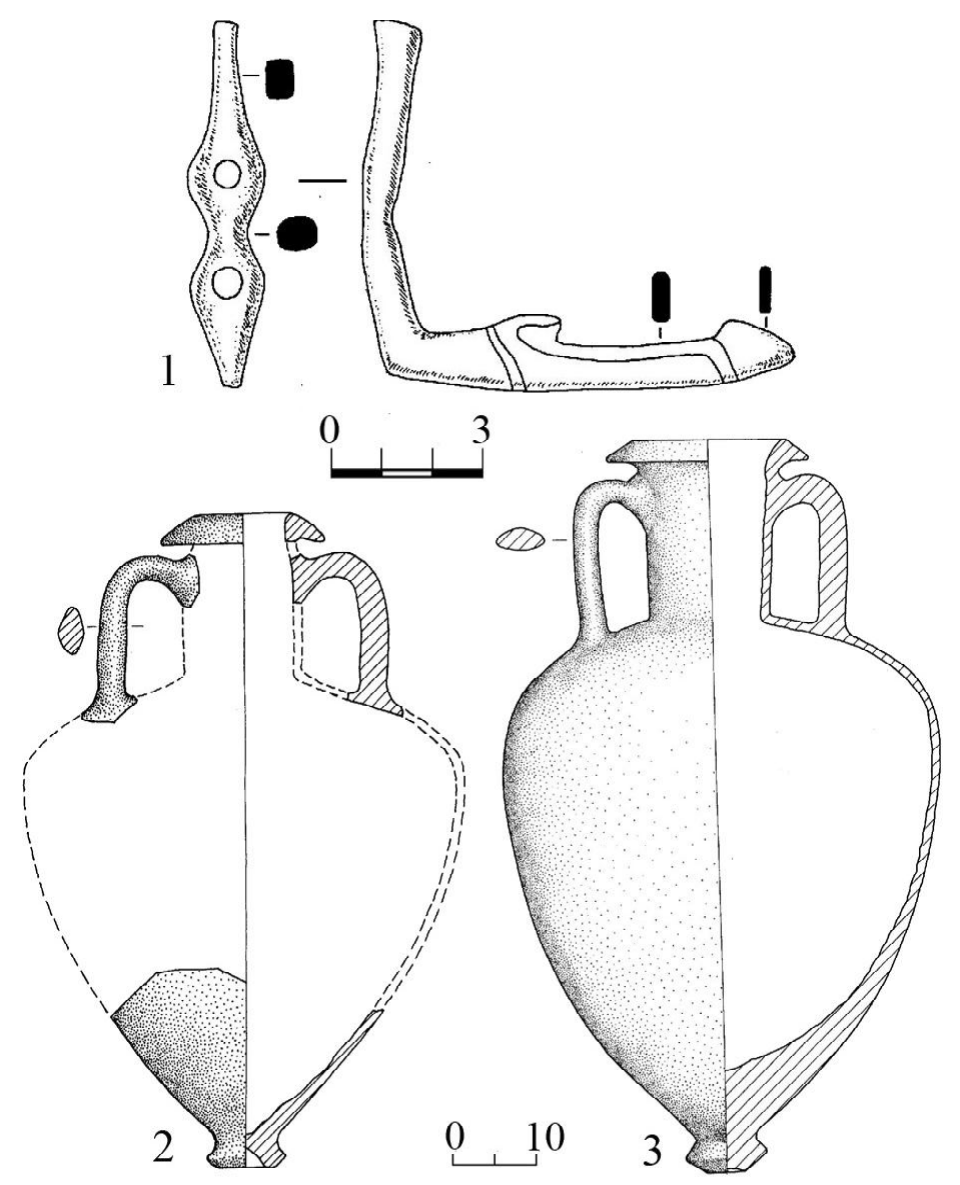

Рис. 4. Прикубанский могильник, погребение 202:

1 - бронзовый псалий; 2, 3 - амфоры

Fig. 4. The Prikubansky burial ground, burial 202:

1 - bronze cheekpiece; 2,3-amphorae 
Н.Ю. Лимберис, И.И. Марченко. Хронология погребений с конской упряжью в зверином стиле

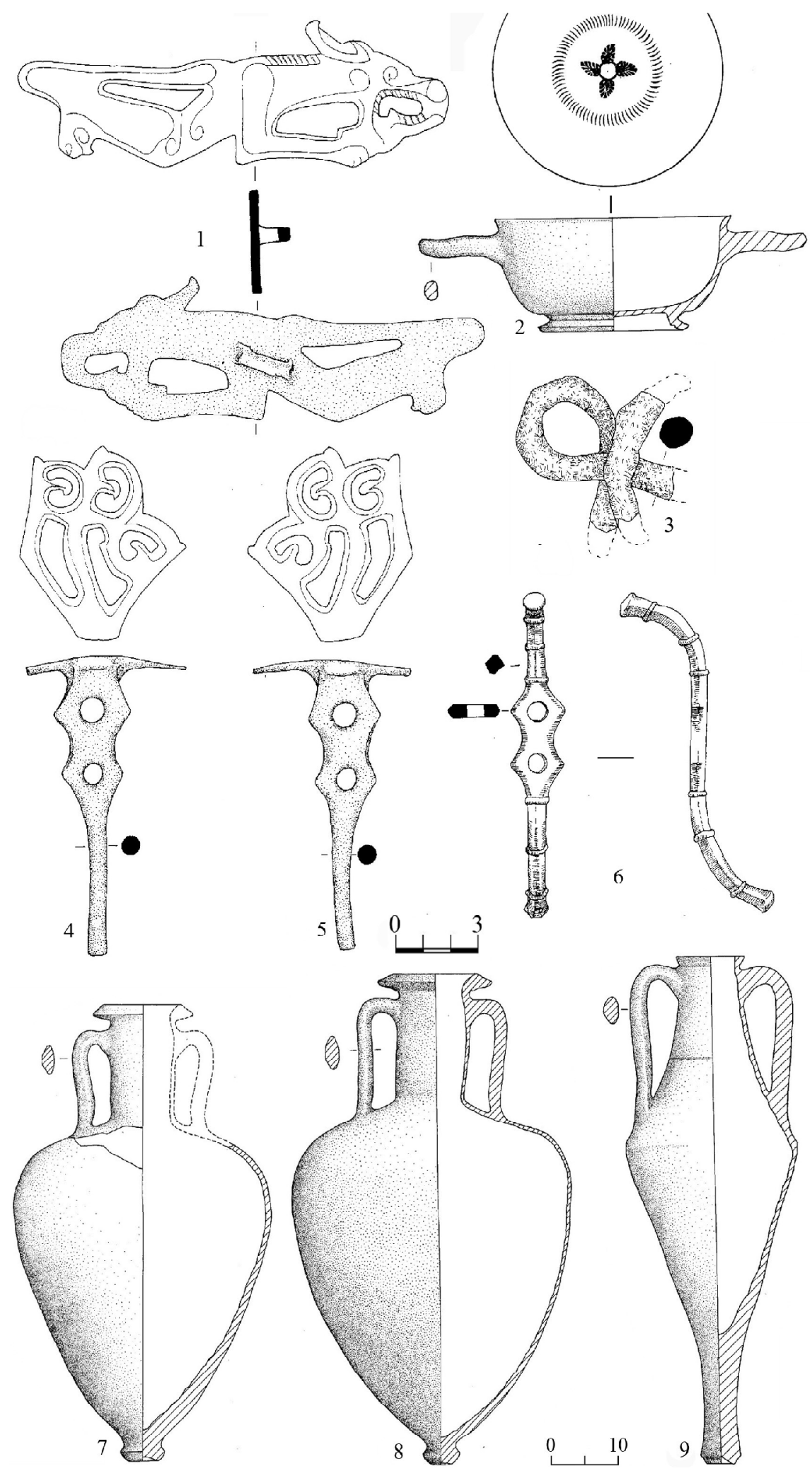

Рис. 5. Прикубанский могильник, погребение 224:

1 - бронзовый налобник; 2 - чернолаковый болсал; 3 - фрагмент железных удил; 4-6 - бронзовые псалии; 7-9- амфоры

Fig. 5. The Prikubansky burial ground, burial 224:

1 - bronze forehead piece; 2 - black glazed bolsal; 3 - fragment of iron bit; 4-6 - bronze cheekpieces; 7-9 - amphorae 


\section{РАННИЙ ЖЕЛЕЗНЫЙ ВЕК}
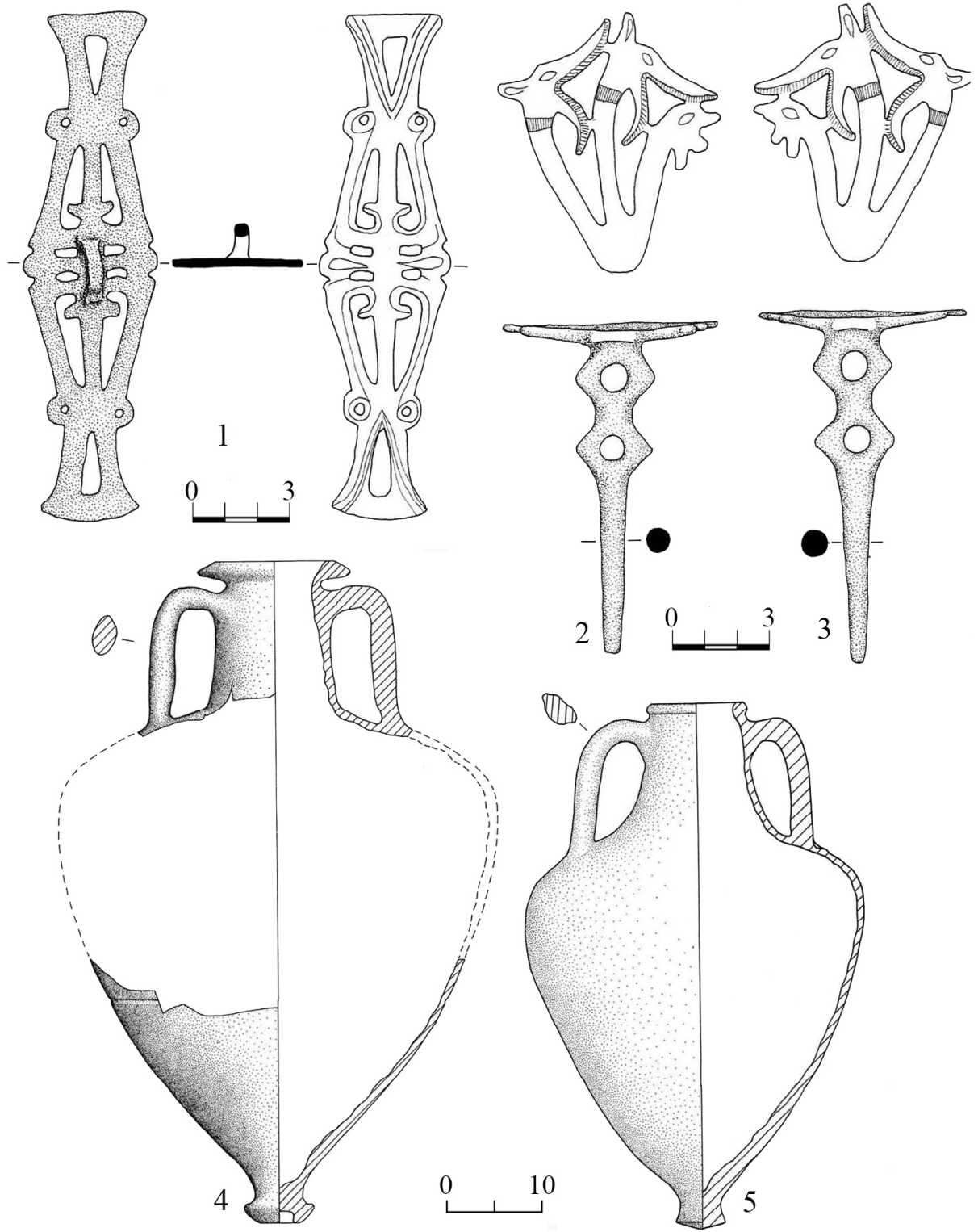

Рис. 6. Прикубанский могильник, погребение 236:

1 - бронзовый налобник; 2, 3 - бронзовые псалии; 4, 5 - амфоры

Fig. 6. The Prikubansky burial ground, burial 236:

1 - bronze forehead piece; 2, 3 - bronze cheekpieces; 4, 5 - amphorae 


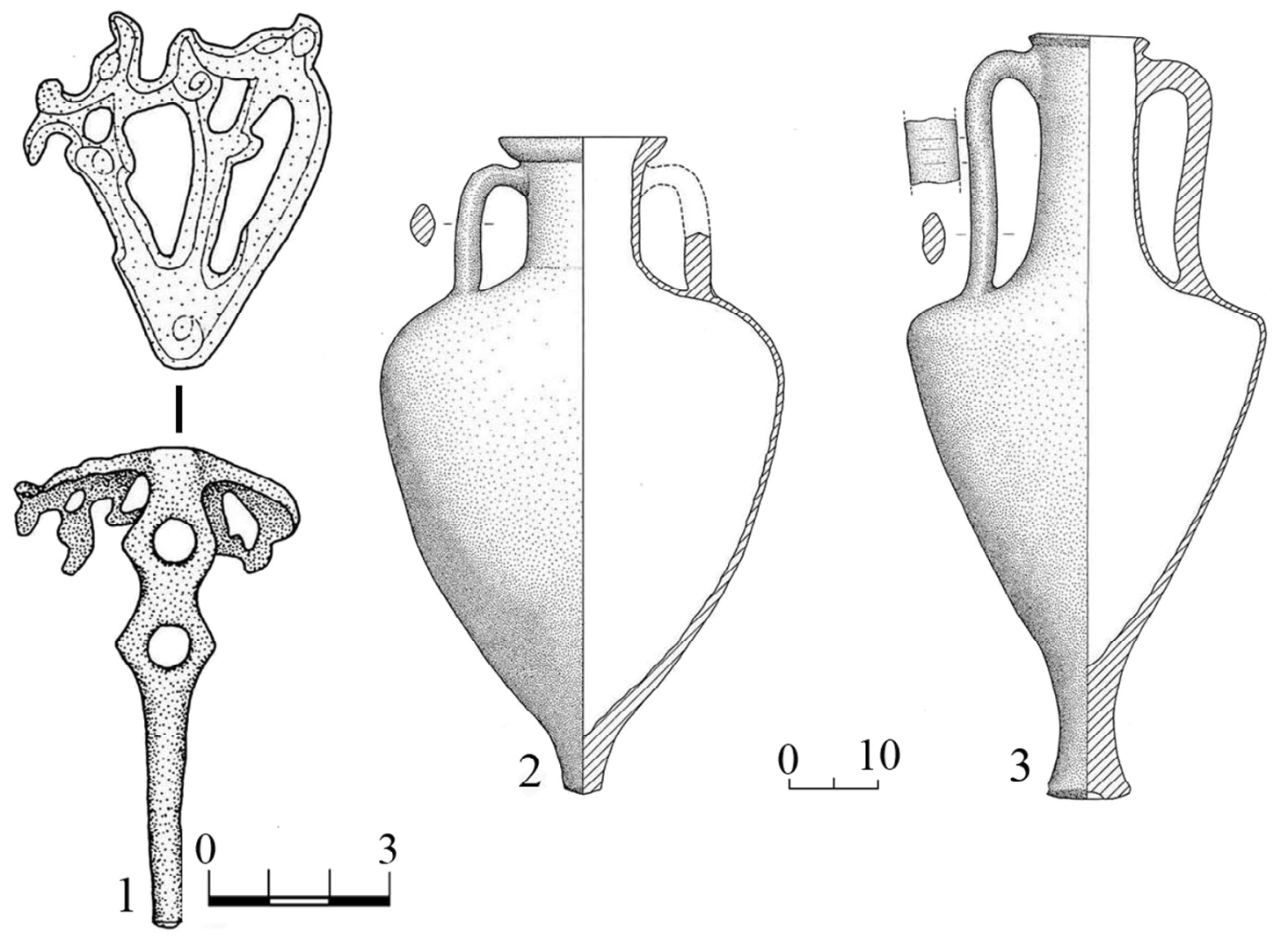

Рис. 7. Прикубанский могильник, погребение 394:

1 - бронзовый псалий; 2, 3 - амфоры

Fig. 7. The Prikubansky burial ground, burial 394:

1 - bronze cheekpiece; 2, 3 - amphorae 

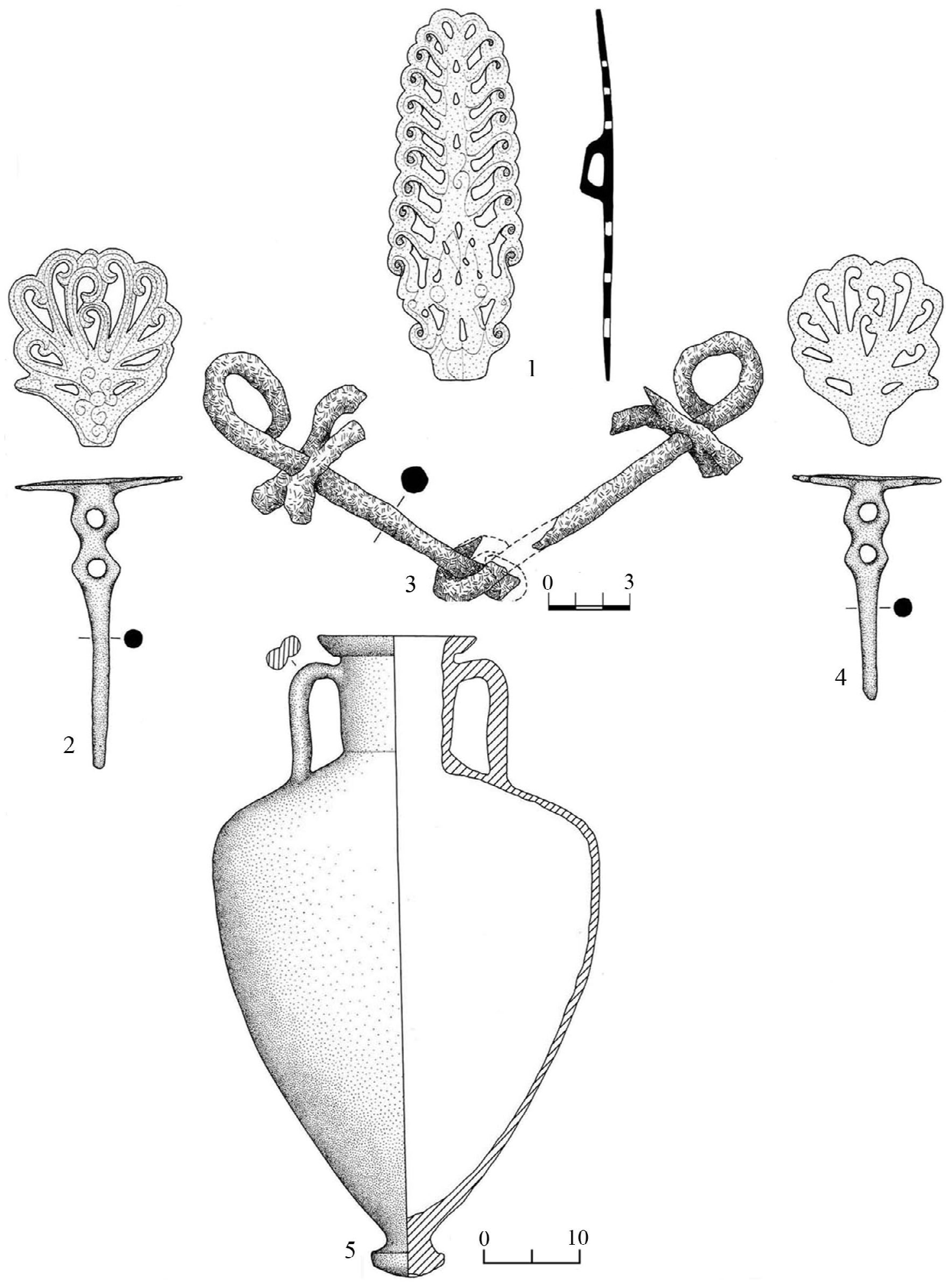

Рис. 8. Прикубанский могильник, погребение 402:

1 - бронзовый налобник; 2, 4 - бронзовые псалии; 3 - железные удила; 5 - амфоры

Fig. 8. The Prikubansky burial ground, burial 402:

1 - bronze forehead piece; 2, 4 - bronze cheekpieces; 3 - iron bit; 5 - amphorae 
Н.Ю. Лимберис, И.И. Марченко. Хронология погребений с конской упряжью в зверином стиле

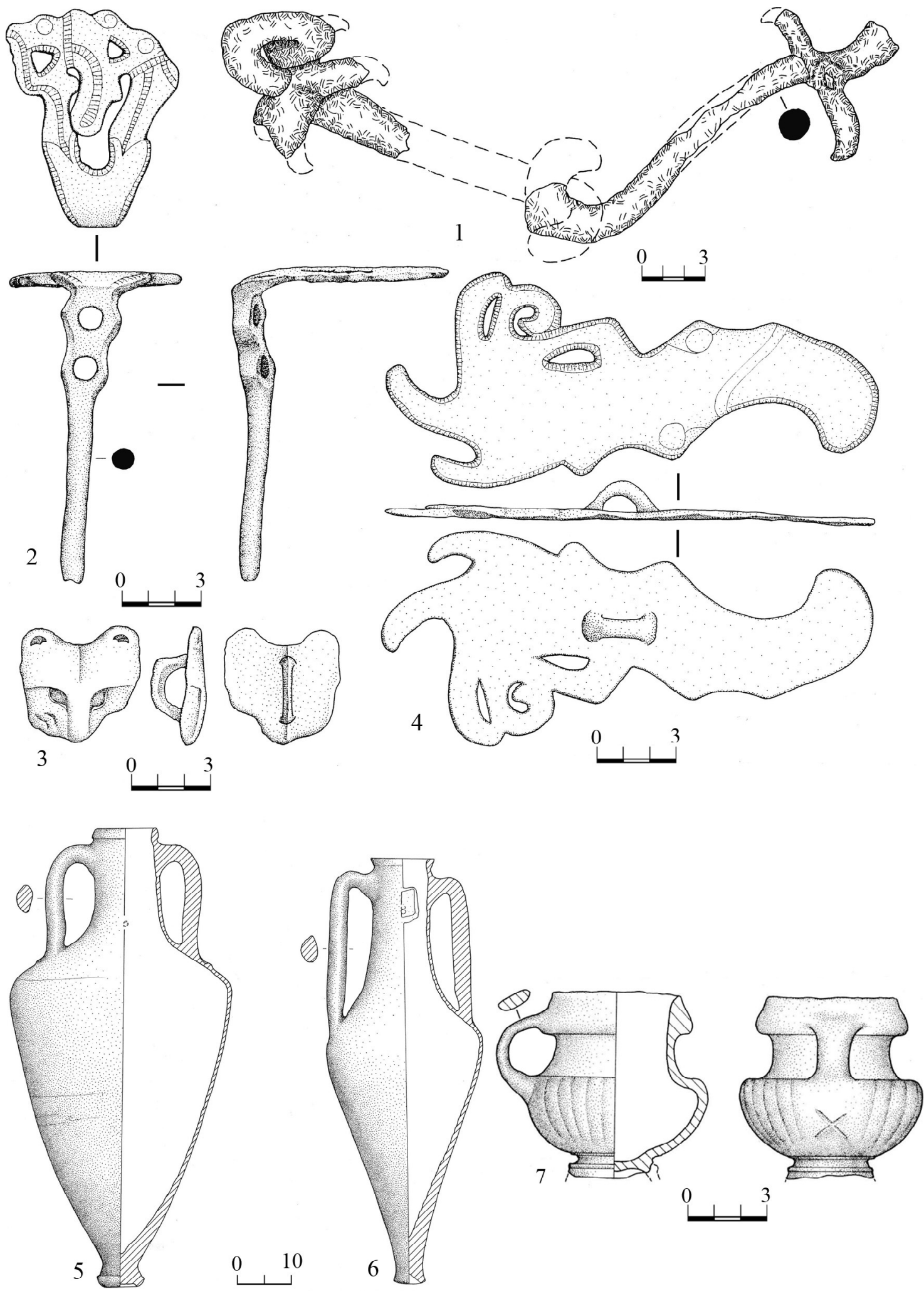

Рис. 9. Прикубанский могильник, погребение 427:

1 - железные удила; 2 - бронзовый псалий; 3 - бронзовая бляха; 4 - бронзовый налобник; 5, 6 - амфоры; 7 - чернолаковая кружка

Fig. 9. The Prikubansky burial ground, burial 427:

1 - iron bit; 2 - bronze cheekpiece; 3 - bronze buckle; 4 - bronze forehead piece; 5, 6 - amphorae; 7 - black glazed mug 


\section{СПИСОК ЛИТЕРАТУРЫ}

1. Галанина, Л. К. Кубанское уздечное снаряжение IV в. до н. э. : (По материалам Елизаветинского кургана, раскопанного Н.И. Веселовским в 1913 г.) / Л. К. Галанина // АСГЭ. - Вып. 37. - СПб. : Изд-во Государственного Эрмитажа, 2005. - С. 97-108.

2. Кац, В. И. Греческие керамические клейма эпохи классики и эллинизма : (опыт комплексного изучения) / В.И. Кац // Боспорские исследования. Вып. XVIII. - Симферополь ; Керчь : Деметра, 2007. $480 \mathrm{c}$.

3. Монахов, С. Ю. Греческие амфоры в Причерноморье. Типология амфор ведущих центровэкспортеров товаров в керамической таре : Каталог-определитель / С. Ю. Монахов. - М. ; Саратов : Киммерида : Изд-во Сарат. ГУ, 2003. - 352 с.

4. Монахов, С. Ю. Косские и псевдокосские амфоры и клейма / С. Ю. Монахов // Stratum Plus. 2014. - № 3. - C. 195-222.

5. Монахов, С. Ю. Керамические комплексы некрополя Панское I / С. Ю. Монахов, Е. Я. Рогов // АМА. - Вып. 8. - Саратов : Изд-во Сарат. ГУ, 1990. - C. 122-151.

6. Монахов, С. Ю. Заметки по локализации керамической тары. IV: амфоры Икоса / C. Ю. Монахов, Н. Ф. Федосеев // АМА. - Вып. 16. - Саратов : Изд-во Сарат. ГУ, 2013. - С. 255-266.

7. Рогов, Е. Я. Расписная и чернолаковая керамика из некрополя Панское I / Е. Я. Рогов, И. В. Тункина // Археологические вести. - № 5. - СПб. : Дмитрий Буланин, 1998. - С. 159-175.

8. Sparkes, B. A. Black and Plaine Pottery of the $6^{\text {th }}, 5^{\text {th }}$ and $4^{\text {th }}$ Centuries B.C. $/$ B. C. Sparkes, L. Talcott // The Athenian Agora. Results of Excavations. Vol. XII. - Princeton : Publ. The American School of Classical Studies at Athens, 1970.-476 p.

\section{REFERENCES}

1. Galanina L.K. Kubanskoe uzdechnoe snaryazheniye IV v. do n.e. (Po materialam Elizavetinskogo kurgana, raskopannogo N.I. Veselovskim v 1913 g.) [Bridle Equipment of the $4^{\text {th }}$ Century BC from Kuban (Based on the Materials from the Elizavetinsky Burial Ground Excavated by N.I. Veselovsky in 1913)]. Arkheologicheskiy sbornik Gosudarstvennogo Ermitazha [Archeological Papers of the State
Hermitage Museum]. Saint Petersburg, State Hermitage Publ., 2005, vol. 37, pp. 97-108.

2. Kats V.I. Grecheskie keramicheskie kleyma epokhi klassiki i ellinizma (opyt kompleksnogo izucheniya) [Greeks Ceramic Stamps of Classical and Hellenistic Epochs (Results of Complex Reseach)]. Bosporskie issledovaniya [Bosporos Studies]. Simferopol; Kerch, Demetra Publ., 2007, vol. XVIII. $480 \mathrm{p}$.

3. Monakhov S.Yu. Grecheskie amfory v Prichernomorye. Tipologiya amfor vedushchikh tsentrov-eksporterov tovarov $v$ keramicheskoy tare. Katalog-opredelitel [Greek Amphorae in the Black Sea Region. The Typology of Amphorae of Main CentresExporters of Goods in Ceramic Containers. CatalogueIdentifier]. Moscow; Saratov, Kimmerida Publ.; Izd-vo SGU, 2003. 352 p.

4. Monakhov S.Yu. Kosskiye i psevdokosskiye amfory i kleyma [Koan and Pseudo-Koan Amphorae and Stamps]. Stratum Plus, 2014, no. 3, pp. 195-222.

5. Monakhov S.Yu., Rogov E.Ya. Keramicheskie kompleksy nekropolya Panskoe I [Ceramics Complexes of the Necropolis Panskoe I]. Antichnyy mir $i$ arkheologiya [The Ancient World and Archaeology]. Saratov, Izd-vo SGU, 1990, iss. 8, pp. 122-151.

6. Monakhov S.Yu., Fedoseev N.F. Zametki po lokalizatsii keramicheskoy tary. IV: amfory Ikosa [Notes on Localization of the Ceramic Containers. IV: Amphorae of Ikos]. Antichniy mir i arkheologiya [The Ancient World and Archaeology]. Saratov, Izd-vo SGU, 2013, iss. 16, pp. 255-266.

7. Rogov E.Ya., Tunkina I.V. Raspisnaya i chernolakovaya keramika iz nekropolya Panskoe I [Painted and Black-Glazed Pottery from the Necropolis Panskoe I]. Arkheologicheskie Vesti [Archaeological News]. Saint Petersburg, Dmitriy Bulanin Publ., 1998, no. 5, pp. 59-175.

8. Sparkes B.A., Talcott L. Black and Plaine Pottery of the 6th, 5th and 4th Centuries B.C. The Athenian Agora. Results of Excavations. Princeton, The American School of Classical Studies at Athens, 1970, vol. XII. 476 p.

\section{СПИСОК СОКРАЩЕНИЙ}

АСГЭ - Археологический сборник Государственного Эрмитажа.

АМА - Античный мир и археология. 
Н.Ю. Лимберис, И.И. Марченко. Хронология погребений с конской упряжью в зверином стиле

\section{Information about the Authors}

Natalya Yu. Limberis, Senior Researcher, Scientific Research Institute of Archaeology, Kuban State University, Stavropolskaya St., 149, 350040 Krasnodar, Russian Federation, meot@mail.ru, https://orcid.org/ 0000-0003-0395-315X

Ivan I. Marchenko, Candidate of Sciences (History), Professor, Department of World History and International Relations, Kuban State University, Stavropolskaya St., 149, 350040 Krasnodar, Russian Federation,meot@mail.ru,https://orcid.org/0000-0001-7319-5214

\section{Информация об авторах}

Наталья Юрьевна Лимберис, старший научный сотрудник НИИ археологии, Кубанский государственный университет, ул. Ставропольская, 149, 350040 г. Краснодар, Российская Федерация, meot@mail.ru, https://orcid.org/0000-0003-0395-315X

Иван Иванович Марченко, кандидат исторических наук, профессор кафедры всеобщей истории и международных отношений, Кубанский государственный университет, ул. Ставропольская, 149, 350040 г. Краснодар, Российская Федерация, meot@mail.ru, https://orcid.org/0000-0001$7319-5214$ 